"Investigation of relationship between personality characteristics and career management of Melli Bank staff, Iran"

\begin{tabular}{ll} 
AUTHORS & $\begin{array}{l}\text { Houshang Yavarpour } \\
\text { Mehraban Hadi Peykani } \\
\text { Azar Gholizadeh }\end{array}$ \\
& $\begin{array}{l}\text { Houshang Yavarpour, Mehraban Hadi Peykani and Azar Gholizadeh (2016). } \\
\text { Investigation of relationship between personality characteristics and career } \\
\text { management of Melli Bank staff, Iran. Problems and Perspectives in } \\
\text { Management, 14(3-si), 407-413. doi:10.21511/ppm.14(3-si).2016.15 }\end{array}$ \\
\hline ARTICLE INFO & http://dx.doi.org/10.21511/ppm.14(3-si).2016.15 \\
\hline ROI & Thursday, 15 September 2016 \\
\hline JOURNAL & "Problems and Perspectives in Management" \\
\hline FOUNDER & LLC "Consulting Publishing Company "Business Perspectives"
\end{tabular}

NUMBER OF REFERENCES

0

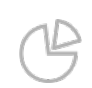

NUMBER OF FIGURES

0

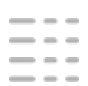

NUMBER OF TABLES

0

(C) The author(s) 2023. This publication is an open access article. 


\title{
Investigation of relationship between personality characteristics and career management of Melli Bank staff, Iran
}

\begin{abstract}
Modern organizations provide their required goods and materials easily from other organizations and even other countries and the only resource that can't be exchanged ideally is human resources, such that an efficient and standard human resources is the most important competitive capital of a country. According to this, current research aims to explain the relationship between personality characteristics with career management of Melli Bank staff in Iran. Statistical population of this research is all employees of Melli Bank central branches which are located in Tehran city. The number of Melli Bank central branches' employees is 2603 and the total number of branches is 28 and an appropriate group sampling method is applied. The research method is descriptive-correlation type. For data gathering, two questionnaires of career path based on Shine model and personality characteristics questionnaire were used. The results show that there is a positive significant relation between the variables of emotional stability personality with the regression coefficient of 0.143 , compatible personality with the regression coefficient of 0.110 , experience- oriented personality mode variable with the regression coefficient of 0.231 and work ethic personality with the regression coefficient of 0.143 and career management of Melli Bank employees. But there is no significant relation between extroversion as one of the personality characteristics and employees' career management.
\end{abstract}

Keywords: career dimensions, career anchors, personality characteristics, Melli Bank.

JEL Classification: M10, M12, J24.

\section{Introduction}

Individual personality dimensions of organization employees are the elements that can help organizations in achieving productivity. Personality characteristics recognition, the way of behavior formation and behavior reasons are the issues of psychology management and as a result of its role and importance it could predict human behaviors in organizations (Cohen, Spector, 2001, pp. 16-20). The effect of personality characteristics on behavior and recognition is sometimes direct and without any mediates, however, sometimes the behavior or recognition is created by impressing mediating factors. Actually, the 5 -factor personality model believes that human is a rational creature that is able to justify his behavior and personality (Rezaiee Nasab et al., 2012). This pattern reflects the major personality recognition-emotional disciplines. This theory provides an appropriate classification of personality that it can be connected to different recognition-emotional process disciplines. Recognition-emotional disciplines are the systems that consist of mediating units such as expectations, objectives and recognition processes that interacts consciously or unconsciously to the individuals' positions and career path. Today's employees think more about their working life compared with past years. They are inclined to grow and develop by a

(C) Houshang Yavarpour, Mehraban Hadi Peykani, Azar Gholizadeh, 2016 Houshang Yavarpour, Ph.D. in the field of Governmental Management, Department of Management, Branch Isfahan (Khorasgan), Islamic Azad University, Isfahan, Iran.

Mehraban Hadi Peykani, Assistant Professor, Department of Management, Branch Isfahan (Khorasgan), Islamic Azad University, Isfahan, Iran.

Azar Gholizadeh, Assistant Professor, Department of Management, cultural management, Branch Isfahan (Khorasgan), Islamic Azad University, Isfahan, Iran. reassuring, long-term and satisfying job. On the other hand, the employees often start their profession by special expectations in order to reach to the highest level of organization and most of them take much attention to their progression, power achievement, take the highest responsibilities and obtain the best rewards (James, 2005). It should be considered that career management is a huge resource for employees in order to satisfy their ideals of career path and to align their skills, interests and values with organization. One of the most important required actions for career path planning is to specify career directions and individuals' inclinations in selecting career paths. Different factors play a role in formation of employees' career path that one of the most important of them is the individuals' personality mode and their selection for the desired job. If a person was obliged to select a job as a result of conditions and economic pressures and that job wasn't fitted to his personality type and couldn't satisfy his psychological needs, then, he will get unmotivated and deprecated quickly. The analysis and investigation of career path development plans in organizations has proved that the more compatibility between career and individual personality mode, the more logical career path they will go through and they will be more motivated (Serinivas, R. and Kandula, 2007).

In this research, employees career management will be investigated in aspect of individuals' personality characteristics. In other words, this research objective is to recognize the personality characteristics that are effective in formation and amplification of employees' career management of Iran Melli Bank employees and provide more facilities for their emergence. In this regard, 5-factor personality model 
is applied as a comprehensive and accepted model in an academic field. This model consists of five dimensions of extroversion, compatibility, neuroticism, openness and loyalty. The relation between these five dimensions of personality and employees career management will be investigated in this research. Research theoretical literature, the definition of dependent variable, independent variable and also the scientific literature intersection are presented before codifying the hypotheses.

\section{Research background}

Yanjun Guan et al. (2015) the role of perceived organizational career management and career management compatibility tend to have turnover among the staff. The relationship between these variables based on the theory of social exchange theory has been making career. In this study, the role of perceived organizational career management and career management compatibility of career success variables (such as salary and satisfying career path) and job characteristics (such as a desire to leave) among 654 employees of companies Chinese, have been investigated. The results show that the compatibility of career and unique role in predicting salary after controlling for demographic variables and understand the impact of organizational career management played. It was also found that both variables management understand career development and career path consistent inverse relation with leaving job, job satisfaction is through these relationships. More results showed that the compatibility of career path, variable impact of perceived organizational career management and job satisfaction increases and this tends to reduce employee turnover.

Ahanchian et al. (2015) in their research investigated attribution style and self-regulation by applying personality modes. The results of structural model showed that the suggested model has a good fitness with the research data and the attribution style can predict the students' self-regulation by mediating their personality, however, attribution style can't afford that alone. Based on this research findings, personality styles mediation has an effect on the relation between attribution style indirect effectiveness and students' self-regulation.

Arizi, Samani and Barati (2015) examined the direct and indirect effects of carrier and individual variables on career satisfaction. The results showed that emotional intelligence, activation personality and job enrichment have a direct effect on career path. However, this research wasn't able to emphasize on indirect effects and maybe its reason was that the employees had detected their job at the low level in aspect of enrichment. The suggestions were made for future researchers in order to design a mediating model and also some suggestions were presented for organizations and managers in order to increase employees' career path satisfaction.

Sadeqi (2014) investigated the relation between (family support, career path efficacy and selfesteem) and students' career path decision making efficacy. The results analysis confirmed the fitness of supposed model after imposing some modified indicators for covariance between self-assessment errors and targeting. The results also showed that family direct support paths and efficacy have a positive and significant effect on students' career path decision making efficacy. The indirect effect of family support and efficacy was obtained positive and significant by mediating self-esteem. According to the importance of students' career path decision making efficacy in specifying education path of their future, the related impressive factors such as the investigated variables should be considered.

Khadem Dezfooli et al. (2012) showed the relation between personality role and job satisfaction by mediating work pressure. As job enrichment has a preventive role on work pressure, it can be expected that individuals' satisfaction can be increased by job enrichment.

\section{Research methodology}

This research is applied in terms of purpose and it investigates the relationship of personality characteristics with career management of Melli Bank staff in Iran. Based on data gathering method, this research is descriptive, since descriptive methods are deployed in order to investigate the estimated models' significance and the relation among variables. This research is applied in terms of purpose and it is descriptive-survey based on data gathering method. In this regard, the questionnaire, sampling and variables analysis are used. The statistical population of this research is all employees of Iran Melli Bank central bureaus which are located in Tehran city. The number of Melli Bank central bureaus' employees is 2603 people and the total number of bureaus is 28 and an appropriate group sampling method is applied. Therefore, based on the calculated sample volume (289 people) and based on the volume of considered society, the number of samples for each administration is specified and in the second stage the number of employees are selected randomly and the related questionnaire is distributed among them.

The obtained data were analyzed by SPSS software. For inferential analysis, correlation test is utilized and also for measuring significance and its type and strength among variables, regression test is used. 


\section{Operational definitions of research variables}

3.1. Independent variable. 3.1.1. 5-factor personality model. The primitive concept of personality visualizes as a social concept and draws based on the role of individual in a community. In fact, an individual gives a kind of personality to his community and on the other hand, population evaluates him based on that personality (Lee et al., 2006). Personality defines based on obvious and dominant property of a person and based on this definition personality is regarded as extrovert, introvert, aggressive, etc. A lot of different and various definitions are presented for personality. However, Sheldon has provided a comprehensive definition that is "personality is a dynamic organization of the conceptual, physical, voluntary and passive aspects of individual" (Martin et al., 2002, pp. 247-256). Personality intention is a specified pattern of behavior and thinking methods that specifies a person's compatibility with an environment. Personality is an abstract concept. The scientists consider these concepts as a structure. This reality (considering personality as a structure) makes its definition difficult. Based on the description we apply the following personality characteristics:

3.1.2. Emotional stability. Emotional stability means the capability of controlling emotions and feelings and the relative sovereignty of rationality.

3.1.3. Compatibility. Compatibility is defined as the state of being loved or accepted by others. The individuals who have this feature are depicted as polite, flexible, reliable, good-humored, cooperative and good-hearted ones. The research background about the relation of this personality feature and job performance is somewhat asymmetrical. The individual who have this personality feature have a lower tolerance of criticism for bad performance (or earning of credits for good performance) compared with other forces. However, a couple of studies showed that the forces who obtain lower scores in compatibility of personality feature, commit more misbehavior in work environment (Sanders, 2008).

3.1.4. Experience-oriented. The individuals who have this feature are imaginary, curious, open-minded and sensitive (in aspect of artistic). Experience oriented is too closely related to intelligence. The ones who are more experience oriented have a more inquiring mind, while the ones who are less experience oriented can't accept new experiences.

3.1.5. Extroversion. One of management achievement factors is related to their ability to handling human relations. The most important aspect of working with human beings is to establish human relations with them. On the other hand, human relations skill is impressed by different factors such as personality characteristics. The forces that are sociable, cordial and associable are susceptible to effective social and human relations. In other words, the extrovert people have stronger human skills and subsequently effective relations can improve manger performance. Actually, extroversion is related to human relations skill and subsequently job performance (Roberts et al., 2005).

3.1.6. Work ethics. Work ethics is regarded as one of personality characteristics and related to diligence, discipline, accuracy, perseverance and accountability. Police forces need this personality feature based on the identity of their duties. As police duties are too important for population and their duties may relate to individuals life. When performance evaluation is based on objective and result, then, the relation between this personality feature and performance will be more obvious (Barrick and Mount, 1991).

3.2. Dependent variable. 3.2.1. Career path. Career path will be created when a person had obtained life and job experiences and these experiences can affect thoughts, values and motivations and make a person strong in facing obstacles (Shine, 1996, pp. 80-88). Shine regards a person's career harbor as a selfconcept that is consisted of 3 components: talent and the ability to perceive oneself, evolved feeling compared with motivations and significant needs and values that are related to career path. The first item is related to the actual experiences of working environment, while the third item is created by individual reactions toward principles and values and we face with them in different social and career achievement (Danziger and Valency, 2005, pp. 293303; Verbruggen and Sels, 2007, pp. 69-83). Shine considers career path pattern as consisted of 8 items: technical competency, management competency, action freedom, action innovation, security, services providence, skills diversity and identity. Shine questionnaire is applied for personnel career path measurement (Hoon Tan and Choo Quek, 2001).

3.2.2. Skills diversity. Diversity is the difference and varicosity of job skill and responsibility that prevents consistency. This is one of the most important criteria that any organization should consider when they design any job.

3.2.3 Freedom of action. This is one of the most important factors in making landmark decisions about career path specification. Action freedom or working independency is a thing that all people are seeking for it and they want to work in an organization that lets them to be more flexible or, in other words, they want to work in an organization that doesn't restrict them with a lot of regulations.

3.3. Technical competency. It is regarded to this fact that a person who has this skill prefers a job that is compatible with his skills. This attitude 
relates to the individuals who have technical skill and the organizations should consider this item in designing positions.

3.4. Management competency. There is a lot of emphasis on responsibility and management position in this personality feature. The ones who want management competency often try to create the circumstances to communicate with the others and they show their ability is responsiveness, control and administration (Stephan, P., Robins, 1996).

3.5. Initiative. It points to creativity and innovation that organizations should consider this item when they design positions and they should assign the ones who have certain qualifications to these positions and in this situation they lead to individual satisfaction and can increase organization performance.

3.6. Security. While job security has lost its primitive meaning and competition and competency have replaced it. However, the organization should create security for some positions. However, it should be mentioned that today most organizations absorb the individuals who have the required competency and skill (Sirinivas, R., Kandula, 2007).

3.7. Services provision. Service provision is the inclination of an individual or an organization to provide services. The important issue that should be considered about this variable is the motivation of organizations and individuals.

3.8. Identity. It is related to the individuals' commitment toward their job and organization and the value that they consider for being member of that organization (Konard, Mengel, 2000).

\subsection{Research hypotheses:}

1. Emotional stability personality has a significant relation with career management of Melli Bank staff.

2. Compatible personality has a significant relation with career management of Melli Bank staff.

3. Experience-oriented personality has a significant relation with career management of Melli Bank staff.

4. Extroversion personality has a significant relation with career management of Melli Bank staff.

5. Loyalty personality has a significant relation with career management of Melli Bank staff.

\section{Empirical results}

4.1 Hypotheses testing. 4.1.1. First hypothesis. Emotional stability personality has a significant relation with career management of Melli Bank staff:

$H_{0}: \mathrm{r}=0$

$H_{1}: \mathrm{r}=/ 0$
Investigating determination coefficient of first hypothesis regression model showed that 8.6 percent of total variations of career management have been explained. On the other hand, the regression coefficient of emotional stability personality $(0.143)$ showed that it has a positive and significant effect on career management at the error level of 5\%, thus, $H_{0}$ is rejected and $H_{1}$ is confirmed ( $\operatorname{sig}=0.000$ and lower than 5 percent). These results show that the higher emotional stability personality, the higher career management level.

Table 1. Emotional stability personality has a significant relation with career management of Melli Bank staff

\begin{tabular}{|l|c|c|c|c|c|}
\hline \multicolumn{1}{|c|}{ Variable } & $\begin{array}{c}\text { Non- } \\
\text { standard } \\
\text { regression } \\
\text { coefficient }\end{array}$ & $\begin{array}{c}\text { Standard } \\
\text { regression } \\
\text { coefficient }\end{array}$ & $\begin{array}{c}\text { Standard } \\
\text { error }\end{array}$ & $\begin{array}{c}t- \\
\text { statistics }\end{array}$ & $\begin{array}{c}\text { Significance } \\
\text { level }\end{array}$ \\
\hline Intercept & 3.441 & 0.108 & 31.771 & 0.000 \\
\hline $\begin{array}{l}\text { Emotional } \\
\text { stability } \\
\text { personality }\end{array}$ & 0.143 & 0.292 & 0.040 & 3.593 & 0.000 \\
\hline $\begin{array}{l}\text { Determination } \\
\text { coefficient }\end{array}$ & \multicolumn{2}{|c|}{8.6} & F-statistics & $\begin{array}{c}12.906 \\
(0.000)\end{array}$ \\
\hline $\begin{array}{l}\text { Moderated } \\
\text { coefficient }\end{array}$ & 7.9 & Durbin-Watson & 2.08 \\
\hline
\end{tabular}

4.1.2. Second hypothesis. Compatible personality has a significant relation with career management of Melli Bank staff:

$H_{0}: \mathrm{r}=0$

$H_{1}: \mathrm{r}=/ 0$

Investigating determination coefficient of second inferior hypothesis regression model showed that 2.3 percent of total variations of career management have been explained by compatible personality mode. On the other hand, the regression coefficient of compatible personality $(0.110)$ showed that it has a positive and significant effect on career management at the error level of $5 \%$, thus, $H_{0}$ is rejected and $H_{1}$ is confirmed (sig $=0.000$ and lower than 5 percent).

Table 2. Compatible personality has a significant relation with career management of Melli bank staff

\begin{tabular}{|l|c|c|c|c|c|}
\hline \multicolumn{1}{|c|}{ Variable } & $\begin{array}{c}\text { Non- } \\
\text { standard } \\
\text { regression } \\
\text { coefficient }\end{array}$ & $\begin{array}{c}\text { Standard } \\
\text { regression } \\
\text { coefficient }\end{array}$ & $\begin{array}{c}\text { Standard } \\
\text { error }\end{array}$ & $\begin{array}{c}t- \\
\text { statistics }\end{array}$ & $\begin{array}{c}\text { Significance } \\
\text { level }\end{array}$ \\
\hline Intercept & 3.545 & 0.098 & & 36.244 & 0.000 \\
\hline $\begin{array}{l}\text { Compatible } \\
\text { personality }\end{array}$ & 0.110 & 0.038 & 0.240 & 2.907 & 0.004 \\
\hline $\begin{array}{l}\text { Determination } \\
\text { coefficient }\end{array}$ & 2.3 & F-statistics & $\begin{array}{c}8.45 \\
(0.000)\end{array}$ \\
\hline $\begin{array}{l}\text { Moderated } \\
\text { coefficient }\end{array}$ & \multicolumn{2}{|c|}{2.1} & Durbin-Watson & 2.01 \\
\hline
\end{tabular}

4.1.3. Third hypothesis. Experience-oriented personality has a significant relation with career management of Melli Bank staff: 
$H_{0}: \mathrm{r}=0$

$H_{1}: \mathrm{r}=/ 0$

Investigating determination coefficient of third hypothesis regression model showed that 4.6 percent of total variations of career management have been explained by experience-oriented personality. On the other hand, the regression coefficient of emotional stability personality (0.231) showed that it has a positive and significant effect on career management at the error level of $5 \%$, thus, $H_{0}$ is rejected and $H_{1}$ is confirmed ( $\mathrm{sig}=0.000$ and lower than 5 percent). These results show that the higher experience-oriented personality, the more promotion of career management level.

Table 3. Experience-oriented personality has a significant relation with career management of Melli Bank staff

\begin{tabular}{|l|c|c|c|c|c|}
\hline \multicolumn{1}{|c|}{ Variable } & $\begin{array}{c}\text { Non- } \\
\text { standard } \\
\text { regression } \\
\text { coefficient }\end{array}$ & $\begin{array}{c}\text { Standard } \\
\text { regression } \\
\text { coefficient }\end{array}$ & $\begin{array}{c}\text { Standard } \\
\text { error }\end{array}$ & $\begin{array}{c}t- \\
\text { statistics }\end{array}$ & $\begin{array}{c}\text { Significance } \\
\text { level }\end{array}$ \\
\hline Intercept & 2.734 & 0.424 & & 6.446 & 0.000 \\
\hline $\begin{array}{l}\text { Experience } \\
\text { oriented } \\
\text { personality }\end{array}$ & 0.231 & 0.090 & 0.213 & 2.557 & 0.012 \\
\hline $\begin{array}{l}\text { Determination } \\
\text { coefficient }\end{array}$ & \multicolumn{2}{|c|}{4.6} & F-statistics & $6.54(0.000)$ \\
\hline $\begin{array}{l}\text { Moderated } \\
\text { coefficient }\end{array}$ & \multicolumn{2}{|c|}{3.9} & Durbin-Watson & 1.957 \\
\hline
\end{tabular}

4.1.4. Fourth hypothesis. Extroversion personality has a significant relation with career management of Melli Bank staff:

$H_{0}: \mathrm{r}=0$

$H_{1}: \mathrm{r}=/ 0$

Investigating determination coefficient of first hypothesis regression model showed that 1.4 percent of total variations of career management have been defined by extroversion personality mode. On the other hand, the regression coefficient of emotional stability personality (0.144) showed that it doesn't have a positive and significant effect on career management at the error level of $5 \%$; thus, $H_{0}$ is confirmed and $H_{1}$ is rejected.

Table 4. Extroversion personality has a significant relation with career management of Melli Bank staff

\begin{tabular}{|l|c|c|c|c|c|}
\hline \multicolumn{1}{|c|}{ Variable } & $\begin{array}{c}\text { Non- } \\
\text { standard } \\
\text { regression } \\
\text { coefficient }\end{array}$ & $\begin{array}{c}\text { Standard } \\
\text { regression } \\
\text { coefficient }\end{array}$ & $\begin{array}{c}\text { Standard } \\
\text { error }\end{array}$ & $\begin{array}{c}t- \\
\text { statistics }\end{array}$ & $\begin{array}{c}\text { Significance } \\
\text { level }\end{array}$ \\
\hline Intercept & 4.191 & 0.174 & & 24.128 & 0.000 \\
\hline $\begin{array}{l}\text { Extroversion } \\
\text { personality } \\
\text { mode }\end{array}$ & 0.144 & 0.065 & 0.185 & -2.194 & 0.130 \\
\hline $\begin{array}{l}\text { Determination } \\
\text { coefficient }\end{array}$ & \multicolumn{2}{|c|}{1.4} & F-statistics & $4.813(0.03)$ \\
\hline $\begin{array}{l}\text { Moderated } \\
\text { coefficient }\end{array}$ & \multicolumn{2}{|c|}{1.2} & Durbin-Watson & 1.879 \\
\hline
\end{tabular}

4.1.5. Fifth hypothesis. Loyalty personality mode has a significant relation with career management of Melli Bank staff:

$H_{0}: \mathrm{r}=0$

$H_{1}: \mathrm{r}=/ 0$

Determination coefficient of first hypothesis regression model showed that 2.6 percent of total variations of career management have been defined by loyalty personality. On the other hand, the regression coefficient of emotional stability personality (0.132) showed that it has a positive and significant effect on career management at the error level of $5 \%$; thus, $H_{0}$ is rejected and $H_{1}$ is confirmed $(\operatorname{sig}=0.000$ and lower than 5 percent $)$.

Table 5. Loyalty personality has a significant relation with career management of Melli Bank staff

\begin{tabular}{|l|c|c|c|c|c|}
\hline Variable & $\begin{array}{c}\text { Non- } \\
\text { standard } \\
\text { regression } \\
\text { coefficient }\end{array}$ & $\begin{array}{c}\text { Standard } \\
\text { regression } \\
\text { coefficient }\end{array}$ & $\begin{array}{c}\text { Standard } \\
\text { error }\end{array}$ & $\begin{array}{c}t- \\
\text { statistics }\end{array}$ & $\begin{array}{c}\text { Significance } \\
\text { level }\end{array}$ \\
\hline Intercept & 3.501 & 0.091 & & 36.001 & 0.000 \\
\hline $\begin{array}{l}\text { Loyalty } \\
\text { personality }\end{array}$ & 0.132 & 0.041 & 0.252 & 2.817 & 0.004 \\
\hline $\begin{array}{l}\text { Determination } \\
\text { coefficient }\end{array}$ & 2.6 & F-statistics & $8.71(0.000)$ \\
\hline $\begin{array}{l}\text { Moderated } \\
\text { coefficient }\end{array}$ & \multicolumn{2}{|c|}{2.4} & Durbin-Watson & 1.89 \\
\hline
\end{tabular}

\section{Conclusions}

Anyone who works has career path that this career path shows progression of his career and leads to individual's progression over the years. Career path defines as a set of jobs or positions that a person experience during his life path. Most employees consider career path as a part their life and it can influence on their identity. If employees are satisfied with the career path management, they will improve their knowledge and skills during career path and they feel success of this reality. Also, the organization reassures about a right combination of individuals who have various skills. Based on the provided explanations following concise results are presented:

First hypothesis: Emotional stability personality mode has a significant relation with career management of Melli Bank staff.

Organizational career progression path management are the activities that an organization is responsible for managing the employees career progression path that is consisted of programs and interventions which are concentrated on comparing career progression path of individuals and organization and it may be in the form of formal and informal activities (education periods, evaluation centers for guidance and consulting for career progression path) (De Vos et al., 2009, pp. 5580) providing the programs such as career progression path for employees of an organization may be 
perceived as giving credit to organization employees for their cooperation in different organization activities (Shine et al. 2007, pp. 53-64) that this leads to individuals job satisfaction, augmentation of employees performance and reduction of organizational psychological pressure. Also, a desired feeling will be created for employees and this feeling make them stay inside organization and they feel achievement (Roziah et al., 2009, pp. 232-254). For analyzing this hypothesis, it can be said that more individuals emotional stability (controlling feelings and emotions), the better career path management. In other words, when an organization has more emotionally stabled employees, then, it can implement better programs for employees' career path, because, in this situation, less resistance for changes will be expected and individuals impose less pressure to organizations to prevent these changes. An individual will gain different experiences during his career path and career path cycle will be elapsed correctly and a person will feel satisfied at time of retirement and like a successful statesman leave politics. As the organization was able to implement an appropriate policies and plans in this field and the reason of this reality is the presence of more emotional stabled employees.

Second hypothesis: Compatible personality mode has a significant relation with career management of Melli Bank staff.

When an individual has a compatible personality, actually, his personality characteristics can be defined in politeness, flexibility, reliability, good-humoring, tolerability, cooperative and being good-hearted and, as it was proved, this personality feature has a positive and significant relation with career management of Melli Bank staff. It can be inferred that these individuals are more compatible and don't follow irrational ideals. These individuals are surrendered to organizations plans and policies and they regard themselves as an organization's solder, especially in bank settings. In this situation, the organization can adjust career path plans better, as there is less resistance against changes and the organization is able to implement the related programs better.

Third hypothesis: Experience oriented personality mode has a significant relation with career management of Melli Bank staff.
For analyzing this hypothesis, it should be mentioned that the individuals who are experience oriented want to gain more experience and also motivated to go through their career path step by step. The policies and plans of organization will be implemented gradually by presence of these individuals. It means that the implementation trend of programs will be slow and subsequently the employees will be more satisfied. These people try to gain more experience and the organization will provide good circumstances for these people and they will enjoy of being in that organization. The organization rotate individuals in different positions and, in this situation, they can gain more experience and as a result the organization will have multi-skill employees and subsequently employees career management will be done well.

Fourth hypothesis: Extroversion personality mode has a significant relation with career management of Melli Bank staff.

The people who have this personality feature are remarkably capable of communicating with other individuals. Actually, human relations are impressed by different factors such as personality characteristics. The forces that are sociable, cordial and associable are susceptible to effective social and human relations. In other words, the individuals who are called extroverted in psychology can have stronger human relations and subsequently efficient human relations can increase management performance. However this personality feature doesn't have a positive and significant relation with career management of Melli Bank staff. In other words, the individuals that have this personality feature can't play a significant role in career path management.

Fifth hypothesis: Loyalty personality mode has a significant relation with career management of Melli Bank staff. When individuals have this type of personality feature (loyal and accountable) career management can be elapsed better and in a way that the individuals try to elapse their career path based on competency and the hidden relations can't play any significant role in career path management. Actually, the individuals try to do their job by being more accountable and competent. Also, when individuals get retired they will feel more satisfied and this can be an important issue for an organization.

\section{References}

1. Ahnchiyan, Mohammad Reza, Arfah, Fatemeh, Bahman Abadi, Somayeh, Aalaiee, Abodllah. (2015). Documents and self-regulation modes, the role of personality modes definition, Behavior Sciences Magazine, 8 (2), pp. 155-164.

2. Arizi, Samani, Seyed Hamid Reza, Barati, Hajar. (2015). The direct and indirect effects of carrier and individual variables on career path satisfaction, Contemporary Psychological Magazine, No. 10, pp. 33-46

3. Barrick, M.R. and Mount, M.K. (1991). The Big Five Personality Dimensions and Job Performance: A MetaAnalysis. Journal of Personnel Psychology, 44, pp. 1-26. 
4. Cohen-Charash, Y. \& Spector, P.E. (2001). The role of justice in organizations: A meta-analysis. Organizational Behavior and Human Decision Processes, 86, pp. 278-321.

5. Danziger, N. and Valency, R. (2005). Career Anchorsi Distribution and Impact on Job Satisfaction, the England Case, and Career Development International, 11 (4), pp. 293-303.

6. Hoon Tan, H. and Choo Quek, B. (2001). An Exploratory Study on the Career Anchors of Educators in Singapore, The Journal of Psychology, 135 (5), pp. 527-545.

7. James W. Clark. (2005). Career Plateausing In Retall Management, Southern Arkansas University.

8. Kandula, Srinivas R. (2007). Performance Management: Strategic, Intervention, Drivers, New Delhi, PrenticeHall of India. (Republished in paperback in 2008 by Phi Learning).

9. Khadem Dezfooli, Z., Arshadi, N. and Taqipoor, A. (2012). The relations between personality characteristics, supervision support and psychological pressure and job satisfaction and work-family conflict, Psychological Researches, No. 15, pp. 48-69.

10. Konrad, A.M. and Mengel, R. (2000). The Impact of Work Life Program on Firm Productivity, Strategic Management Journal, 21 (12), pp. 12-25.

11. Ley, T., Kump, Lindstaedt B., Albert S.N., Maiden D., N.A.M., \& Jones, S.V. (2006). Competence and Performance in Requirements Engineering: Bringing Learning to the Workplace. Proceedings of LOKMOL 2006, 2nd Workshop on Learner oriented Knowledge Management and KM oriented e-Learning, Crete, Greece, October $02,2006, \mathrm{pp} .148-158$

12. Martin, B.A., Brown, C.C. \& Hunt, S.T. (2002). How effective are people at faking on personality questionnaires? Personality and Individual Differences, 32 (2), pp. 247-256.

13. Rezaee Nasab T, Mosavi Far S, Khosro Javid M. (2012). Attribution style and personality characteristics in the students, Proceed Semin 6 Stud Ment Health, 4 (1), pp. 2-14 [Persian].

14. Roberts, B.W., Chernyshenko, O.S., Stark, S. and Goldberg, L.R. (2005). The Structure of Conscientiousness: An Empirical Investigation Based on Seven Major Personality Questionnaires. Personnel Psychology, 58 (1), pp. 103-140.

15. Sadeqi, Ahmad. 2014. Investigating the relation between (family support, career path efficacy and self-esteem) and students' career path decision making efficacy. Psychological achievements magazine (nurturing and psychological sciences), Shahid Chamran University of Ahwaz, spring and summer, 4 (1), 22nd year, pp. $227-244$.

16. Sanders, B. (2008). Using Personality Traits to Predict Police Officer Performance, An International Journal of Police Strategies \& Management, 31 (1), pp. 129-140.

17. Schein, E.H. (1996). Career Anchors Revisited Implications for Career Development in the 21st Century, Academy of Management Executive, 10 (40), pp. 80-88.

18. Verbruggen, M. and Sels, L. (2007). Unraveling the Relationship between Organizational Career Management and the Need for External Career Counseling, Journal of Vocational Behavior, 71, pp. 69-83.

19. Yanjun Guan, Wenxia Zhou, Lihui Ye, Peng Jiang, Yixin Zhou. (2015). Perceived organizational career management and career adaptability as predictors of success and turnover intention among Chinese employees, Journal of Vocational Behavior, 88, June 2015, pp. 230-237. 